\title{
Strategiczne wyzwania w zakresie pomiaru i zarządzania ryzykiem utraty reputacji w bankach
}

\author{
STRATEGIC CHALLENGES IN MEASURING AND \\ MANAGING REPUTATIONAL RISK IN BANKS
}

\begin{abstract}
Celem artykutu jest przeglqd i analiza regulacji nadzorczych oraz dotychczasowych badań w zakresie zarzqdzania ryzykiem utraty reputacji we wspótczesnym systemie bankowym ze szczególnym uwzględnieniem metod identyfikacji $i$ pomiaru tego rodzaju ryzyka oraz instrumentów stosowanych $w$ celu jego ograniczania. Zdaniem autora ryzyko utraty reputacji należy definiować jako oddzielny rodzaj ryzyka, jednak ze względu na jego specyficznq naturę nie powinien być on zarzqdzany odrębnie, ale $w$ sposób zintegrowany z podstawowymi rodzajami ryzyka. Strategicznym postulatem dotyczqcym mechanizmów redukcji ryzyka utraty reputacji $w$ systemie bankowym jest zaś ograniczenie ryzyka upadłości duzych, wzajemnie powiqzanych ze sobq instytucji poprzez zmniejszenie ich rozmiarów oraz ograniczenie wzajemnych połaczeń, a także usprawnienie zarzqdzania procesem restrukturyzacji i uporzqdkowanej likwidacji banków.
\end{abstract}

Słowa kluczowe: banki, ryzyko utraty reputacji, ryzyko operacyjne.

JEL Codes: G21, G28, G32.

\section{Wprowadzenie}

Jednym z najważniejszych a zarazem najtrudniej mierzalnych aspektów działalności bankowej jest reputacja rozumiana jako dobre imię i zaufanie wszystkich interesariuszy a zwłaszcza deponentów. Utrata przez bank dobrego imienia i zaufania ze strony interesariuszy (strata reputacyjna) może być istotnym źródłem efektu zarażania i to zarówno poprzez kanał zachowania deponentów (run na banki), rynek międzybankowy, jak też system płatności i rozliczeń. Najbardziej nieprzewidywalny efekt może ona powodować jednak poprzez kanał zachowania deponentów, którzy bardzo często postrzegają problemy jednego banku jako problemy całego sektora i dopiero zdecydowana i wiarygodna reakcja instytucji sieci bezpieczeństwa (np. udzielenie rządowych gwarancji rozszerzające ochronę systemu gwarantowania depozytów) mogą przywrócić zaufanie do banków. Reputacja banków jest przy tym nierozerwalnie związana $z$ reputacją organów sieci bezpieczeństwa. Społeczeństwo postrzega bezpieczeństwo sektora bankowego poprzez pryzmat reputacji czuwającej na nim sieci bezpieczeństwa, ale także reputacja sieci bezpieczeństwa zależy od 
bezpieczeństwa i stabilności banków ${ }^{1}$. To sprzężenie zwrotne powoduje jednak, iż wszelkie zaburzenia wymagaja nadzwyczajnych $\mathrm{i}$ wiarygodnych, $\mathrm{w}$ oczach społeczeństwa, działań, aby tą nadszarpniętą reputację przywrócić.

Celem artykułu jest przegląd i analiza regulacji nadzorczych oraz dotychczasowych badań w zakresie zarządzania ryzykiem utraty reputacji we współczesnym systemie bankowym ze szczególnym uwzględnieniem metod identyfikacji i pomiaru tego rodzaju ryzyka, a także instrumentów stosowanych w celu jego ograniczania. Ponadto wskazane zostaną związki pomiędzy ryzykiem utraty reputacji i ryzykiem operacyjnym oraz przedstawione zostaną strategiczne postulaty dotyczące mechanizmów redukcji ryzyka utraty reputacji w systemie bankowym.

$\mathrm{Z}$ uwagi na istotny wzrost znaczenia oraz zmiany w postrzeganiu roli ryzyka utraty reputacji, do realizacji celu wykorzystano post kryzysowe dokumenty Bazylejskiego Komitetu Nadzoru Bankowego oraz regulacje Europejskiego Urzędu Nadzoru Bankowego, a także wyniki badań naukowych w zakresie ryzyka utraty reputacji przeprowadzanych w USA i krajach Europy Zachodniej po ostatnim globalnym kryzysie finansowym.

\section{Źródla ryzyka utraty reputacji}

W literaturze przedmiotu oraz regulacjach ostrożnościowych, którym podlegają banki do grupy najważniejszych rodzajów indywidualnego ryzyka $w$ działalności bankowej zaliczono ryzyko płynności, kredytowe, rynkowe i operacyjne. O ile jednak z uwagi na wskazane rodzaje ryzyka banki muszą przestrzegać określonych norm płynności i wypłacalności, o tyle z tytułu ponoszonego ryzyka utraty reputacji nie podlegają żadnym ilościowym ograniczeniom. $Z$ uwagi na charakter ryzyka utraty reputacji, które wiąże się $\mathrm{z}$ utratą dobrego imienia na rynku istnieje szczególny związek pomiędzy nim a innymi rodzajami ryzyka i to nie tylko o charakterze indywidualnym, lecz także systemowym.

Materializacja ryzyka utraty reputacji powodująca utratę dobrego imienia przez bank ma wpływ na jego postrzeganie na rynku przez inne podmioty zwiększając tym samym poziom ponoszonego przez nich ryzyka rozliczenia, czy też ryzyka kontrahenta ${ }^{2}$. Spadek zaufania do pojedynczego banku może być zatem istotnym źródłem efektu zarażania w całym sektorze bankowym prowadząc do wzrostu ryzyka systemowego ${ }^{3}$. Co ważne problemy $\mathrm{z}$ zaufaniem mogą być wielowymiarowym źródłem ryzyka systemowego zarówno o charakterze ponadsektorowym (np. związanym z czynnikami behawioralnymi, sektorowym (np. wynikającym z zawodności instytucji otoczenia sektora bankowego), jak też indywidualnym (np. poprzez materializację indywidualnego ryzyka w poszczególnych bankach). Szczególna relacja wiazże jednak ryzyko utraty reputacji z ryzykiem operacyjnym, gdyż bardzo często obydwa mają te same przyczyny, z których najważniejszą jest zawodność czynnika ludzkiego (grupy osób, czy nawet pojedynczego człowieka) ${ }^{4}$. Od wprowadzenia Basel 2 w 2004 r. po dzień dzisiejszy, nawet po zmianach dokonanych względem tego rodzaju ryzyka z końcem 2017 r., wciąż

\footnotetext{
${ }^{1}$ A. D. Morrison, L. White: Reputational contagion and optimal regulatory forbearance, Journal of Financial Economics 2013, Vol. 110, Issue 3, s. 642-658.

${ }^{2}$ L. Onyiriuba: Emerging Market Bank Lending and Credit Risk Control, Elsevier, London 2016, s. 35-40.

${ }^{3}$ European Central Bank: Financial Stability Review, May 2017, s. 3.

${ }^{4}$ J. Koleśnik: Bezpieczeństwo systemu bankowego. Teoria i praktyka, Difin, Warszawa 2011, s. 64-67.
} 
jednak ryzyko operacyjne definiuje się wyłącznie jako ryzyko straty wynikającej z niewłaściwych lub zawodnych procesów wewnętrznych, ludzi i systemów lub też ze zdarzeń zewnętrznych ${ }^{5}$. Definicja ta obejmuje także ryzyko prawne, lecz nie obejmuje ryzyka strategicznego i ryzyka utraty reputacji. Rozpoczynając prace nad Basel 3, Bazylejski Komitet Nadzoru Bankowego określił ryzyko utraty reputacji jako ryzyko wynikające z negatywnego postrzegania przez klientów, kontrahentów, udziałowców, inwestorów, wierzycieli, analityków rynku, innych interesariuszy lub organów regulacyjnych, które mogą negatywnie wpłynąć na zdolność banku do utrzymania istniejących lub ustanowienia nowych relacji biznesowych oraz stałego dostępu do źródeł finansowania (np. poprzez rynki międzybankowe lub sekurytyzacyjne). Ryzyko utraty reputacji jest przy tym wielowymiarowe i odzwierciedla postrzeganie innych uczestników rynku. Ponadto istnieje w całej organizacji, a narażenie na ryzyko utraty reputacji jest zasadniczo funkcją adekwatności wewnętrznych procesów zarządzania ryzykiem w banku, a także sposobu i efektywności, z jaką kierownictwo reaguje na wpływy zewnętrzne związane z operacjami bankowymi ${ }^{6}$. Pomimo, iż w Basel 3 nie dodano wymogów kapitałowych $\mathrm{z}$ tytułu ryzyka utraty reputacji to ryzyko to zostało uwzględnione (według definicji z 2009 r.) w wytycznych dotyczących identyfikacji i zarządzania ryzykiem wydanych w październiku 2017 roku$^{7}$.

Powyższa definicja ryzyka utraty reputacji przedstawiona przez Komitet Bazylejski stała się swoistym drogowskazem dla organów sieci bezpieczeństwa finansowego w wielu krajach. Trzeba jednak zauważyć, iż tworząc własne definicje korzystały one także z dorobku naukowego wielu badaczy. Niektóre z nich bazowały na dość ogólnych sformułowaniach postrzegając ryzyko utraty reputacji jako różnicę pomiędzy oczekiwaniami interesariuszy przedsiębiorstwa a jego osiagnięciami ${ }^{8}$, czy też jako ryzyko straty finansowej spowodowanej zmianą zachowań interesariuszy przedsiębiorstwa, która wynika z pogorszenia jego reputacji'. Inne zaś odnosily się do postrzegania ryzyka utraty reputacji poprzez pryzmat zdarzeń, których wystąpienie może powodować zmianę zachowania interesariuszy przedsiębiorstwa prowadząc do powstania straty finansowej w tym podmiocie ${ }^{10}$. Z punktu widzenia banków z krajów Unii Europejskiej kluczowa jest jednak definicja ryzyka utraty reputacji stosowana przez Europejski Urząd Nadzoru Bankowego (EUNB), zgodnie z którą ryzyko utraty reputacji oznacza rzeczywiste lub potencjalne ryzyko, na jakie narażone są zyski, fundusze własne lub płynność instytucji w wyniku utraty przez nią reputacji ${ }^{11}$. EUNB zwraca uwagę, iż ryzyko utraty reputacji powinno być uwzględniane przy ocenie ryzyka operacyjnego ze

\footnotetext{
${ }^{5}$ Basel Committee on Banking Supervision: International Convergence of Capital Measurement and Capital Standards. A revised framework. Comprehensive Version, Basel 2006.

${ }^{6}$ Basel Committee on Banking Supervision: Enhancements to the Basel II framework, Basel 2009.

${ }^{7}$ Basel Committee on Banking Supervision: Guidelines Identification and management of step-in risk, Basel 2017.

${ }^{8}$ P. Mitic: Reputation risk: measured, International Journal of Safety and Security Engineering 2018, Vol. 8, Issue 1, s. 171-180.

${ }^{9}$ M. Tonello: Reputation risk - a corporate governance perspective, The Conference Board Research Report No. R-1412-07-WG, 2007, s. 22.

${ }^{10}$ N. Gatzert: The impact of corporate reputation and reputation damaging events on financial performance: empirical evidence from the literature, European Management Journal 2015, Vol. 33, No. 6, s. 485-499.

${ }^{11}$ European Banking Authority: Guidelines on common procedures and methodologies for the supervisory review and evaluation process (SREP), EBA/GL/2014/13, s. 17.
} 
względu na silne powiązania między nimi (np. większość zdarzeń ryzyka operacyjnego ma istotny wpływ na reputacje). Jednak wynik oceny ryzyka utraty reputacji nie powinien być odzwierciedlony w samej punktacji ryzyka operacyjnego, ale powinien być traktowany jako część analizy modelu biznesowego lub oceny ryzyka płynności, ponieważ głównym skutkiem, jaki może powodować jego materializacja jest obniżenie zysku oraz utrata zaufania do instytucji przez inwestorów, deponentów lub uczestników rynku międzybankowego.

\section{Pomiar ryzyka utraty reputacji}

Zainteresowanie ryzykiem utraty reputacji $\mathrm{w}$ sektorze bankowym wzrosło $\mathrm{w}$ ciagu ostatnich dwudziestu lat po wystapieniu kilku znaczących przykładów strat operacyjnych spowodowanych oszustwami wewnętrznymi, fizyczną utratą aktywów oraz zakłóceniami działalności i awariami systemów. Zasadne staje się zatem pytanie w jaki sposób mierzyć ryzyko utraty reputacji i jakie powinno być miejsce (udział) tego rodzaju ryzyka $\mathrm{w}$ identyfikowaniu banków o znaczeniu systemowym, których problemy (także na skutek utraty reputacji) mogą wywołać globalny lub regionalny kryzys. Obecnie jedyną instytucją, która dokonuje identyfikacji globalnych banków o znaczeniu systemowym ze wszystkich krajów świata jest Rada Stabilności Finansowej (FSB), która korzysta w tym celu z wytycznych opracowanych przez Bazylejski Komitet Nadzoru Bankowego $^{12}$. Wśród 13 parametrów każdego banków, podzielonych na 5 kategorii o równych wagach istotności, nie ma jednak bezpośredniego odniesienia do reputacji badanych podmiotów, pomimo, iż bez watpienia ten rodzaj ryzyka ma istotny wpływ na skalę działalności transgranicznej, wielkość banku, czy powiązanie z systemem finansowym ${ }^{13}$. Niestety także na szczeblu Unii Europejskiej, w której wprowadzone zostały zasady identyfikacji banków o znaczeniu systemowym w skali UE, stosowne wytyczne w sprawie kryteriów ich identyfikacji i oceny, wydane w 2014 r. przez Europejski Urząd Nadzoru Bankowego, nie zawierają bezpośredniego odniesienia do reputacji banku. Wśród 49 wskaźników fakultatywnych, które także mogą być, decyzją kraju członkowskiego, wykorzystywane do identyfikacji banków o znaczeniu systemowym w skali UE został wskazany wskaźnik „Potencjalne narażenie na ryzyko utraty reputacji” ${ }^{\prime 4}$. Nie sprecyzowano jednak, w jaki sposób właściwe organy powinny przeprowadzić ocenę ryzyka utraty reputacji, na jakie narażony jest bank, ograniczając się jedynie do stwierdzenia, iż należy w tym celu uwzględniać sposób zarządzania instytucjac, jej model biznesowy, produkty oraz otoczenie, w którym działa. EUNB zwraca uwagę, iż ryzyko utraty reputacji jest bardziej istotne dla dużych instytucji, w szczególności tych, których akcje lub obligacje są notowane na giełdzie lub tych, które są aktywne na rynku międzybankowym. Dokonując oceny ryzyka utraty reputacji należy uwzględniać zarówno czynniki wewnętrzne, jak i zewnętrzne lub zdarzenia, które

\footnotetext{
12 Basel Committee on Banking Supervision: Global systemically important banks: revised assessment methodology and the higher loss absorbency requirement, Basel 2018, s. 5.

${ }^{13}$ M. Allahrakha, P. Glasserman, H. P. Young: Systemic Importance Indicators for 33 U.S. Bank Holding Companies: An Overview of Recent Data, OFR Brief Series 2015, No. 15-01, s. 1-7.

${ }^{14}$ European Banking Authority: Guidelines on the criteria to determine the conditions of application of Article 131(3) of Directive 2013/36/EU (CRD) in relation to the assessment of other systemically important institutions (O-SIIs), EBA/GL/2014/10, s. 12.
} 
mogą budzić obawy o reputację banku. Pod uwagę należy brać zarówno zdarzenia mierzalne (np. liczbę kar nałożonych na dany bank), jak też niemierzalne (wydźwięk kampanii medialnych związanych $\mathrm{z}$ bankiem) (tabela 1.) oraz interakcje ryzyka utraty reputacji z innymi rodzajami ryzyka, na które narażony jest bank.

Tabela 1. Zdarzenia, które należy uwzględniać przy ocenie ryzyka utraty reputacji banku

\begin{tabular}{|c|c|}
\hline \multicolumn{2}{|r|}{ Zdarzenia } \\
\hline mierzalne & niemierzalne \\
\hline $\begin{array}{l}\text { liczba kar nałożonych na bank w } \\
\text { ciągu roku (przez instytucje sieci } \\
\text { bezpieczeństwa, organy } \\
\text { podatkowe itp.) } \\
\text { - liczba skarg konsumentów i jej } \\
\text { zmiana } \\
\text { - dostępne wskaźniki rynkowe (np. } \\
\text { obniżenie ratingu lub zmiany cen } \\
\text { akcji na przestrzeni roku) }\end{array}$ & $\begin{array}{l}\text { - kampanie medialne i inicjatywy stowarzyszeń konsumentów } \\
\text { przyczyniające się do pogorszenia odbioru i reputacji banku wśród } \\
\text { opinii publicznej } \\
\text { - negatywne zdarzenia wpływające na inne podmioty, jeżeli te są } \\
\text { kojarzone przez opinię publiczną z całym sektorem finansowym lub } \\
\text { grupą banków } \\
\text { - współpraca z sektorami i podmiotami niepostrzeganymi dobrze przez } \\
\text { opinię publiczną (przemysł zbrojeniowy, kraje objęte embargiem itp.) } \\
\text { bądź osobami i krajami figurującymi na listach sankcyjnych }\end{array}$ \\
\hline
\end{tabular}

Źródło: opracowanie własne na podstawie European Banking Authority: Guidelines on common procedures and methodologies for the supervisory review and evaluation process (SREP) and supervisory stress testing. Consolidated version, EBA/GL/2014/13, s. 111.

Uwzględnianie przy ocenie ryzyka utraty reputacji banku liczby kar nałożonych na niego przez np. instytucje sieci bezpieczeństwa, czy organy podatkowe jest jednak dyskusyjne. Badania wykazały bowiem, iż największe straty reputacyjne, jakich doznają banki nie są związane z sankcjami prawnymi lub regulacyjnymi, ale z ujawnianymi przez nie stratami operacyjnymi. Biorąc zaś pod uwagę typ zdarzenia, które generuje straty operacyjne, okazuje się, iż największe straty reputacyjne powoduja oszustwa, a w dalszej kolejności zdarzenia związane z niewłaściwymi praktykami dotyczącymi zatrudnienia (np. mobbing lub dyskryminacja), zarządzania procesami oraz praktyk biznesowych. Wśród linii biznesowych najbardziej narażone na ryzyko utraty reputacji są zaś „handel i sprzedaż” oraz „płatności i rozliczenia”, które też generują największe straty reputacyjne ${ }^{15}$. Istotność wpływu zdarzeń na reputację banku zależy także od specyfiki kraju. W krajach anglosaskich (USA, Wielka Brytania, Kanada) największy wpływ na reputację ma ogłoszenie przez bank strat spowodowanymi oszustwami wewnętrznymi. Reakcja rynku jest tym silniejsza, im wyższa jest strata lub gdy jej dokładna wysokość nie jest upubliczniana ${ }^{16}$. Uwzględnianie przy ocenie ryzyka utraty reputacji banku liczby kar nałożonych na niego musi uwzględniać wysokość tych kar oraz „stopień szkodliwości” czynu, za popełnienie którego została ona nałożona. Parametr też nie może być jednak wykorzystywany do porównywania poziomu ryzyka utraty reputacji banków z różnych krajów z uwagi na odmienną politykę organów nadzoru bankowego ${ }^{17}$, czy też instytucji chroniącej konkurencję na rynku w zakresie

\footnotetext{
${ }^{15}$ F. Fiordelisi, M.-G. Soana, P. Schwizer: Reputational losses and operational risk in banking, The European Journal of Finance 2014, Vol. 20, Issue 2, s. 105-124.

${ }^{16}$ X. Jiang: Operational risk and its impact on North American and British banks, Applied Economics 2018, Vol. 50, No. 8, s. 920-933.

${ }^{17}$ M. Zaleska: Zarządzanie kryzysowe, [w:] Świat bankowości, red. M. Zaleska, Difin, Warszawa 2019, s. 8386.
} 
nakładania kar (kary łączne, kary za każde przewinienie), katalogu sankcji stosowanych wobec banków, a nawet upubliczniania nałożonych kar (tabela 2.).

Tabela 2. Liczba kar i ich wysokość nałożona na banki przez FED, EBC oraz KNF w latach 2016-2018

\begin{tabular}{|c|c|c|c|c|c|c|}
\hline \multirow[t]{3}{*}{ Rok } & \multicolumn{6}{|c|}{ Organ nakładajacy kary } \\
\hline & \multicolumn{2}{|c|}{ FED } & \multicolumn{2}{|c|}{ EBC } & \multicolumn{2}{|c|}{ KNF } \\
\hline & Liczba kar & $\begin{array}{c}\text { Łączna } \\
\text { wartość kar } \\
\text { (mln USD) }\end{array}$ & Liczba kar & $\begin{array}{c}\text { Łączna } \\
\text { wartość kar } \\
\text { (mln EUR) }\end{array}$ & Liczba kar & $\begin{array}{c}\text { Łączna } \\
\text { wartość kar } \\
(\mathrm{mln} \text { PLN) }\end{array}$ \\
\hline 2016 & 7 & 257 & 0 & 0 & 1 & 0,1 \\
\hline 2017 & 15 & 691 & 4 & 14 & 0 & 0,0 \\
\hline 2018 & 16 & 224 & 8 & 8 & 5 & 6,9 \\
\hline
\end{tabular}

Źródło: opracowanie własne na podstawie danych FED, EBC, KNF [dostęp 1 XII 2019]

Trzeba też pamiętać, iż niektóre kary nakładane na banki nie są związane z naruszeniem przez nie regulacji bankowych, czy też przepisów chroniących konsumentów lub konkurencję, lecz wynikają z niezgodności ich działań z interesami politycznymi kraju macierzystego. Przykładem może być kara w wysokości 8,9 mld USD nałożona w 2014 r. przez władze amerykańskie na francuski bank BNP Paribas za to, iż ten stosował walutę amerykańską w rozliczeniach z krajami obłożonymi przez USA sankcjami (Iran, Sudan, Syria) ${ }^{18}$.

Konstruując miary poziomu ryzyka utraty reputacji w bankach należy jednak pamiętać, iż prawdopodobieństwo utraty reputacji wzrasta wraz ze wzrostem zysków i wielkości banku. W przypadku poniesienia przez bank straty operacyjnej, kurs jego akcji notowanych na giełdzie spada bardziej w przypadku banków bardziej rentownych niż dla banków o niższej rentowności. Efekt ten wynika z zaskoczenia inwestorów nieoczekiwaną stratę operacyjną ponoszoną przez rentowne banki. Reakcja inwestorów jest także silniejsza na straty operacyjne ponoszone przez duże banki niż przez mniejsze banki. Prawdopodobieństwo utraty reputacji maleje jednak wraz ze wzrostem poziomu kapitalizacji banku. Inwestorzy zakładają bowiem, iż lepiej skapitalizowane banki mają mniejszą skłonność do pokusy nadużycia niż banki o słabej kapitalizacji, tym samym spadek kuru akcji powodowany przez stratę operacyjną jest mniejszy w przypadku dobrze skapitalizowanych banków ${ }^{19}$.

Wewnętrzy pomiar ryzyka utraty reputacji w bankach musi odbywać się $\mathrm{w}$ powiązaniu $\mathrm{z}$ pomiarem ryzyka operacyjnego pomimo, iż $\mathrm{W}$ świetle regulacji nadzorczych formalnie są to dwa odrębne rodzaje ryzyka. W tym celu banki, stosujacce metody podstawowe do zarządzania ryzykiem operacyjnym, powinny stosować do wewnętrznego pomiaru ryzyka utraty reputacji przede wszystkim proste metody scoringowe wykorzystujące np. ocenę wydźwięku informacji medialnych o danym banku $^{20}$. Banki, których akcje są notowane na rynku regulowanym mogą także

\footnotetext{
${ }^{18}$ T. Kubota: Concern About Financial Stability Following the Recent US Legal Expansionism: International Law and East Asian Perspectives [w:] Central Banking and Financial Stability in East Asia, red. F. Rövekamp, M. Bälz, H. G. Hilpert, Springer, Cham 2015, s. 168-183.

${ }^{19}$ F. Fiordelisi, M.-G. Soana, P. Schwizer: The determinants of reputational risk in the banking sector, Journal of Banking \& Finance 2013, Vol. 37, Issue 5, s. 1359-1371.

${ }^{20}$ P. Cherchiello: Statistical models to measure corporate reputation, Journal of Applied Quantitative Methods 2011, Vol. 6, Issue 4, s. 58-71.
} 
wykorzystać w tym celu pomiar reakcji ceny akcji na ogłoszenie istotnej straty operacyjnej. Jeżeli wartość rynkowa banku spadnie bardziej niż kwota deklarowanej straty, to różnica ta będzie odpowiadała wartości zmaterializowanego ryzyka utraty reputacji. Wartość rynkowa banku spada bowiem proporcjonalnie do strat spowodowanych zdarzeniami zewnętrznymi, ale ponad dwukrotnie bardziej w sytuacji poniesienia strat dotyczących oszustw wewnętrznych ${ }^{21}$. W przypadku banków, które stosuja zaawansowane modele zarządzania ryzykiem operacyjnym uzasadnionym postulatem jest rozszerzenie tych modeli poprzez uwzględnienie w nich także ryzyka utraty reputacji, przy wykorzystaniu, istniejących już dziś metod deterministycznych oraz modeli stochastycznych. Można przy tym wyróżnić co najmniej trzy różne modele ryzyka utraty reputacji stosowane w praktyce: proste podejście deterministyczne, model stochastyczny wykorzystujący założenia dystrybucyjne oraz rozszerzenie drugiego modelu, uwzględniające zdolność banku do radzenia sobie ze zdarzeniami mogącymi prowadzić do utraty reputacji ${ }^{22}$.

\section{Wdrażanie mechanizmów ograniczania ryzyka utraty reputacji w bankach}

Badania największych amerykańskich i europejskich instytucji finansowych (banków oraz zakładów ubezpieczeń) wskazują, iż od 2006 r. stale przybywa wśród nich podmiotów, które zdefiniowały i wdrożyły procedury zarządzania ryzykiem utraty reputacji. W 2006 r. spośród 82 tego typu podmiotów, których kapitalizacja rynkowa przekraczała $1 \mathrm{mld}$ USD, jedynie 10 miało wdrożone takie procedury, podczas gdy po dziesięciu latach było już 36 takich podmiotów. W tym czasie ponad czterokrotnie wzrosła także liczba odniesień do ryzyka utraty reputacji $\mathrm{w}$ raportach rocznych badanych podmiotów (tabela 3.). Świadomość konieczności wdrażania procedur zarządzania ryzykiem utraty reputacji była przy tym wyższa wśród większych podmiotów oraz instytucji europejskich ${ }^{23}$.

Tabela 3. Procedury zarządzania ryzykiem utraty reputacji oraz odniesienia do tego ryzyka w raportach rocznych wśród amerykańskich i europejskich instytucji finansowych

\begin{tabular}{|c|c|c|c|c|c|c|c|c|c|c|}
\hline & \multicolumn{10}{c|}{ Rok } \\
\cline { 2 - 12 } & 2006 & 2007 & 2008 & 2009 & 2010 & 2011 & 2012 & 2013 & 2014 & 2015 \\
\hline Liczba instytucji & 10 & 13 & 20 & 21 & 24 & 30 & 29 & 33 & 33 & 36 \\
Liczba odniesień & 138 & 165 & 213 & 275 & 323 & 376 & 472 & 538 & 659 & 629 \\
\hline
\end{tabular}

Źródło: opracowanie własne na podstawie D. Heidinger, N. Gatzert: Awareness, determinants and value of reputation risk management: Empirical evidence from the banking and insurance industry, Journal of Banking \& Finance 2018, Vol. 91, s. 106-118.

Szczególnym zagrożeniem dla reputacji banku, jest faktyczna, a czasami nawet domniemana, współpraca ze światem przestępczym. Zdarza się jednak, iż niektóre banki

\footnotetext{
${ }^{21}$ P. Jason, P. de Fontnouvelle: Measuring Reputational Risk: The Market Reaction to Operational Loss Announcements Federal Reserve Bank of Boston, Boston 2005.

${ }^{22}$ C. Eckert, N. Gatzert: Modeling operational risk incorporating reputation risk: An integrated analysis for financial firms, Insurance: Mathematics and Economics 2017, Vol. 72, s. 122-137.

${ }^{23}$ D. Heidinger, N. Gatzert: Awareness, determinants and value of reputation risk management: Empirical evidence from the banking and insurance industry, Journal of Banking \& Finance 2018, Vol. 91, s. 106-118.
} 
świadomie podejmują współpracę z przestępcami stanowiąc wręcz dla niech swoistą przykrywkę, dzięki której mogą oni bezkarnie prowadzić swoje interesy na niespotykaną dotychczas skalę. Powiązania banków $\mathrm{z}$ przestępcami pomimo, iż zdarzają się w praktyce trzeba jednak traktować jako sytuację nadzwyczajna, która z całą mocą i stanowczością zwalczana jest przez wszystkie organy państwowe, w tym przez instytucje sieci bezpieczeństwa finansowego. Oczywiście skuteczność tych działań jest wprost proporcjonalna do sprawności funkcjonowania całego państwa $\mathrm{i}$ jego rzeczywistej woli walki z przestępczością. Przypadki powiązań banków z przestępcami moga przy tym dotyczyć nie tylko małych lokalnych banków, ale nawet globalnych banków międzynarodowych. Regulacje unijne, wprowadzone po upadku Bank of Credit and Commerce International ${ }^{24}$, istotnie ograniczyły ryzyko utraty reputacji $\mathrm{w}$ całym unijnym systemie bankowym, praktycznie uniemożliwiając celową i świadomą współpracę banków ze światem przestępczym. Trzeba jednak pamiętać, iż regulacje te nie zapobiegają utracie reputacji przez bank na skutek zdarzeń zaliczanych do kategorii oszustw wewnętrznych. W tym przypadku kluczowe staje się właściwe ukształtowanie kompetencji organów zarządzających $\mathrm{w}$ banku oraz wprowadzenie odpowiednich procedur. Liczne badania wykazały przy tym, iż banki o większym odsetku niezależnych członków organów zarządzających są mniej narażone na oszustwa wewnętrzne. Wielkość zarządu jest zaś ujemnie i nieliniowo związana z możliwością zdarzeń ryzyka operacyjnego, a niejednorodność wieku i stażu pracy osób wchodzących w skład takiego organu może mieć niekorzystny wpływ na funkcję monitorowania przez niego zdarzeń mogących prowadzić do materializacji ryzyka utraty reputacji ${ }^{25}$. Postulat ograniczania ryzyka utraty reputacji poprzez modyfikację ładu korporacyjnego banków w celu zwiększania roli $\mathrm{w}$ podejmowaniu decyzji przez niezależnych członków organów zarządzających nie może być jednak postulatem uniwersalnym i ponadczasowym. Badania dowiodły bowiem, iż w przypadku banków ład korporacyjny przyjazny dla akcjonariuszy wiąże się z wyższym ryzykiem systemowym w sektorze bankowym. W szczególności ład korporacyjny przyjazny akcjonariuszom powoduje większe ryzyko dla większych banków oraz banków, które mają siedziby w krajach, gdzie instytucje publiczne są bardziej skłonne udzielać pomocy instytucjom finansowym $\mathrm{w}$ trudnej sytuacji. Zwiększanie roli niezależnych członków organów zarządzających w procesie podejmowania decyzji nie jest zatem rozwiązaniem problemu ryzyka utraty reputacji banku w sytuacji, gdy banki są świadome, iż należą do grupy zbyt dużych, aby upaść, co wykorzystuja $\mathrm{w}$ swoich relacjach $\mathrm{z}$ instytucjami sieci bezpieczeństwa. Dopiero eliminacja tego problem, czyli redukcja systemowego znaczenia banków sprawi, iż ład korporacyjny przyjazny dla akcjonariuszy będzie także przyczyniał się do ograniczania ryzyka utraty reputacji ${ }^{26}$.

Ważnym elementem, który musi być uwzględniany w procesie zarządzania ryzykiem utraty reputacji $\mathrm{w}$ banku są informacje o zdarzeniach oznaczających materializację ryzyka operacyjnego. Informacje takie nie są jedynie odbierane jako

\footnotetext{
${ }^{24}$ S. Platt: Criminal capital; how the finance industry facilitates crime, Palgrave Macmillan, London 2015, s. VIII.

${ }^{25}$ T. Wang, C. Hsu: Board composition and operational risk events of financial institutions, Journal of Banking \& Finance 2013, Vol. 37, Issue 6, s. 2042-2051.

${ }^{26}$ D. Anginer, A. Demirguc-Kunt, H. Huizinga, K. Ma: Corporate governance of banks and financial stability, Journal of Financial Economics 2018, Vol. 130, Issue 2, s. 327-346.
} 
obniżenie wyniku finansowego banku, ale także jako ujawnienie poważnych problemów w systemie kontroli wewnętrznej, czy też nawet przestępczym działaniu niektórych pracowników. Skala wpływu jest przy tym odwrotnie proporcjonalna do liczby źródeł tych informacji. Większa liczba źródeł informacji, w szczególności źródeł wiarygodnych osłabia negatywny wpływ samej informacji na reputację banku. Banki muszą jednak szybko reagować na informacje o zdarzeniach oznaczających materializację ryzyka operacyjnego, jeśli chcą złagodzić ich skutki w zakresie reputacji i rozwiać obawy inwestorów. Oznacza to zatem potrzebę dokładnego monitorowania mediów oraz zaangażowanie osób zarządzających ryzykiem do formułowania komunikatów $\mathrm{i}$ koordynacji polityki informacyjnej banku w zakresie ponoszonego przez niego ryzyka ${ }^{27}$. Wpływ na poziom ryzyka utraty reputacji ma także jakość ujawniania informacji o ryzyku operacyjnym oraz o stratach z tytułu jego materializacji. Jak wskazują badania jakość ta zależy jednak głownie od działań organów nadzoru bankowego, przy czym duży wpływ ma na nią także struktura właścicielska, aktywność komitetu audytu, czy też otoczenie regulacyjne sprzyjające rozwojowi konkurencji na rynku ${ }^{28}$.

Przyśpieszenie procesu wdrażania mechanizmów ograniczania ryzyka utraty reputacji w bankach nastapiło po ostatnim globalnym kryzysie finansowym, do czego istotnie przyczyniły się działania Europejskiego Urzędu Nadzoru Bankowego, który wydał w 2015 r. szczegółowe wytyczne dotyczące procedur i metod stosowanych w ramach procesu przeglądu i oceny nadzorczej banków. Wytyczne te wprowadziły obowiązek oceny, czy dany bank wdrożył odpowiednie rozwiazania, strategie, procesy i mechanizmy zarządzania ryzykiem utraty reputacji. Na podstawie tych wytycznych oraz praktyki w sektorze bankowych, która ukształtowała się pod koniec drugiej dekady obecnego stulecia można stwierdzić, iż pożądany kształt systemu zarządzania ryzykiem utraty reputacji w banku powinien odznaczać się następującymi cechami ${ }^{29}$ :

- polityka i proces identyfikacji, zarządzania i monitorowania tego ryzyka musi być sformalizowany oraz proporcjonalny w stosunku do wielkości banku,

- bank musi posiadać plany awaryjne uwzględniające konieczność działań w zakresie ryzyka utraty reputacji w przypadku wystapienia kryzysu,

- bank musi przeprowadzać testy warunków skrajnych lub analizy scenariuszy, aby oceniać wtórne skutki materializacji ryzyka utraty reputacji,

- bank musi dbać o ochronę swojej marki (np. poprzez kampanie informacyjne podejmowane na skutek zdarzeń, mogących zaszkodzić jego reputacji),

- bank musi uwzględniać wpływ planów biznesowych na swoją reputację.

Warto jednak wskazać, iż wprowadzanie kolejnych wymogów regulacyjnych w zakresie mechanizmów ograniczania ryzyka utraty reputacji nie może prowadzić do jego przeregulowania, ani też nie może wynikać z chęci wpływania na inne dziedziny

\footnotetext{
${ }^{27}$ A. Barakat, S. Ashby, P. Fenn, C. Bryce: Operational risk and reputation in financial institutions: Does media tone make a difference? Journal of Banking \& Finance 2019, Vol. 98, s. 1-24.

${ }_{28}$ A. Barakat, K. Hussainey: Bank governance, regulation, supervision, and risk reporting: Evidence from operational risk disclosures in European banks, International Review of Financial Analysis 2013, Vol. 30, s. 254-273.

${ }^{29}$ European Banking Authority: Guidelines on common procedures and methodologies for the supervisory review and evaluation process (SREP) and supervisory stress testing. Consolidated version, EBA/GL/2014/13, s. 117 .
} 
życia społecznego. To drugie zagrożenie dotyczy sytuacji, kiedy organy nadzoru wskazują bankom zagrożenia dla ich reputacji wynikające np. z przeprowadzania transakcji z legalnie działającymi podmiotami z branży zbrojeniowej, czy górniczej. Paradoksalnie to właśnie takie postępowanie organów nadzoru bankowego może podważać zaufanie do systemu regulacyjnego oraz obniżać reputację instytucji sieci bezpieczeństwa, a dalszej kolejności także samych banków ${ }^{30}$. Interesującym uzupełnieniem, ale nie alternatywą dla regulacji nadzorczych, może stanowić rozwój produktów (polis) ubezpieczeniowych z tytułu ryzyka utraty reputacji. Trzeba jednak wyraźnie zaznaczyć, iż produkty te znajdują się dopiero we wstępnej fazie rozwoju a same zakłady ubezpieczeń przyznają, że nie mają jeszcze odpowiedniego doświadczenia $\mathrm{w}$ identyfikacji, pomiarze oraz wycenie tego rodzaju ryzyka ${ }^{31}$. Wykorzystanie produktów ubezpieczeniowych do zabezpieczania się banków z tytułu ryzyka utraty reputacji, może także generować, niekorzystny $\mathrm{z}$ punktu widzenia stabilności całego sektora finansowego, transfer tego typu ryzyka do segmentów rynku słabiej nadzorowanych przez instytucje sieci bezpieczeństwa.

\section{Podsumowanie}

Dokonany przegląd i analiza regulacji oraz dotychczas przeprowadzonych badań w zakresie zarządzania ryzykiem utraty reputacji we współczesnym systemie bankowym ze szczególnym uwzględnieniem metod identyfikacji i pomiaru tego rodzaju ryzyka, a także instrumentów stosowanych w celu jego ograniczania wykazał, iż ryzyko utraty reputacji należy definiować jako oddzielny rodzaj ryzyka. Jednak ze względu na jego specyficzną naturę nie powinien być on zarządzany odrębnie, ale w sposób zintegrowany z podstawowymi rodzajami ryzyka, w szczególności z ryzykiem operacyjnym, także w celu uniknięcia potencjalnego podwójnego liczenia wymogów kapitałowych. Straty spowodowane utratą reputacji mogą znacznie przekroczyć pierwotną stratę operacyjną, a ich zaniedbanie może prowadzić do poważnego niedoszacowania niektórych rodzajów ryzyka operacyjnego (zwłaszcza zdarzeń związanych z nadużyciami wewnętrznymi). W chwili obecnej straty operacyjne, które moga powodować utratę reputacji nie zawsze są brane pod uwagę przy modelowaniu i ocenie ryzyka operacyjnego. Modele ryzyka operacyjnego standardowo powinny zostać rozszerzone poprzez uwzględnienie w nich także ryzyka utraty reputacji, co nie powinno stanowić dużego wyzwania zarówno dla banków, jak i dla organów nadzoru bankowego, gdyż już dziś istnieją metody deterministyczne oraz modele stochastyczne uwzględniające zdolność banku do radzenia sobie ze zdarzeniami mogącymi prowadzić do utraty reputacji.

Biorąc pod uwagę charakter ryzyka utraty reputacji w kontekście zdarzeń, jakie miały miejsce podczas ostatniego globalnego kryzysu finansowego trzeba jednak stwierdzić, iż strategicznym postulatem dotyczącym mechanizmów redukcji ryzyka utraty reputacji w systemie bankowym, zarówno pojedynczych banków, jak też całego sektora bankowego jest ograniczenie ryzyka upadłości dużych, wzajemnie powiązanych ze sobą instytucji poprzez zmniejszenie ich rozmiarów oraz ograniczenie wzajemnych połączeń, a także usprawnienie zarządzania procesem restrukturyzacji i uporządkowanej

\footnotetext{
${ }^{30}$ J. A. Hill: Regulating Bank Reputation Risk, Georgia Law Review 2020, Vol. 54, s. 523-602.

${ }^{31}$ N. Gatzert, J. T. Schmit, A. Kolb: Assessing the Risks of Insuring Reputation Risk, The Journal of Risk and Insurance 2016, Vol. 83, Issue 3, s. 641-679.
} 
likwidacji banków. Konieczne jest także dokonanie zmian w obecnie stosowanych kryteriach identyfikacji banków o znaczeniu systemowym, zarówno tych na szczeblu globalnym, jak też identyfikujących banki systemowo ważne w danym kraju, poprzez obligatoryjne uwzględnianie ich potencjalnego narażenia na ryzyko utraty reputacji.

Nie ulega także wątpliwości, iż alternatywą dla powyższych działań w kontekście ryzyka utraty reputacji nie może być dyscyplina rynkowa. O ile jeszcze w połowie pierwszej dekady tego stulecia wydawało się, iż dyscyplina rynkowa może być dopełnieniem regulacji nadzorczych to ostatni kryzys finansowy całkowicie pogrzebał te nadzieje. Rynek finansowy nie może być bowiem źródłem inspiracji dla strategii banków i jednocześnie zapewniać wzajemne oddziaływanie o charakterze samodyscyplinującym. Oparcie się wyłącznie na oddziaływaniu rynkowym prowadzi do efektów stadnych i tylko potęguje zagrożenia dla reputacji banków a nie redukuje go. Idea dyscypliny rynkowej może sprawdzić się jedynie w ograniczonym zakresie w przypadku ryzyka utraty reputacji konkretnego banku.

\section{Bibliografia}

Allahrakha M., Glasserman P., Young H. P.: Systemic Importance Indicators for 33 U.S. Bank Holding Companies: An Overview of Recent Data, OFR Brief Series 2015, No. 15-01, s. 1-7.

Anginer D., Demirguc-Kunt A., Huizinga H., Ma K.: Corporate governance of banks and financial stability, Journal of Financial Economics 2018, Vol. 130, Issue 2, s. 327-346.

Barakat A., Ashby S., Fenn P., Bryce C.: Operational risk and reputation in financial institutions: Does media tone make a difference? Journal of Banking \& Finance 2019, Vol. 98, s. 1-24.

Barakat A., Hussainey K.: Bank governance, regulation, supervision, and risk reporting: Evidence from operational risk disclosures in European banks, International Review of Financial Analysis 2013, Vol. 30, s. 254-273.

Basel Committee on Banking Supervision: Enhancements to the Basel II framework, Basel 2009.

Basel Committee on Banking Supervision: Global systemically important banks: revised assessment methodology and the higher loss absorbency requirement, Basel 2018.

Basel Committee on Banking Supervision: Guidelines Identification and management of step-in risk, Basel 2017.

Basel Committee on Banking Supervision: International Convergence of Capital Measurement and Capital Standards. A revised framework. Comprehensive Version, Basel 2006.

Cherchiello P.: Statistical models to measure corporate reputation, Journal of Applied Quantitative Methods 2011, Vol. 6, Issue 4, s. 58-71.

Eckert C., Gatzert N.: Modeling operational risk incorporating reputation risk: An integrated analysis for financial firms, Insurance: Mathematics and Economics 2017, Vol. 72, s. 122-137.

European Banking Authority: Guidelines on common procedures and methodologies for the supervisory review and evaluation process (SREP) and supervisory stress testing. Consolidated version, EBA/GL/2014/13.

European Banking Authority: Guidelines on the criteria to determine the conditions of application of Article 131(3) of Directive 2013/36/EU (CRD) in relation to the assessment of other systemically important institutions (O-SIIs), EBA/GL/2014/10.

European Central Bank: Financial Stability Review, May 2017.

Fiordelisi F., Soana M.-G., Schwizer P.: Reputational losses and operational risk in banking, The European Journal of Finance 2014, Vol. 20, Issue 2, s. 105-124.

Fiordelisi F., Soana M.-G., Schwizer P.: The determinants of reputational risk in the banking sector, Journal of Banking \& Finance 2013, Vol. 37, Issue 5, s. 1359-1371.

Gatzert N., Schmit J. T., Kolb A.: Assessing the Risks of Insuring Reputation Risk, The Journal of Risk and Insurance 2016, Vol. 83, Issue 3, s. 641-679. 
Gatzert N.: The impact of corporate reputation and reputation damaging events on financial performance: empirical evidence from the literature, European Management Journal 2015, Vol. 33, No. 6, s. 485-499.

Heidinger D., Gatzert N.: Awareness, determinants and value of reputation risk management: Empirical evidence from the banking and insurance industry, Journal of Banking \& Finance 2018, Vol. 91, s. 106-118.

Hill J. A.: Regulating Bank Reputation Risk, Georgia Law Review 2020, Vol. 54, s. 523-602.

Jason P., de Fontnouvelle P.: Measuring Reputational Risk: The Market Reaction to Operational Loss Announcements Federal Reserve Bank of Boston, Boston 2005.

Jiang X.: Operational risk and its impact on North American and British banks, Applied Economics 2018, Vol. 50, No. 8, s. 920-933.

Koleśnik J.: Bezpieczeństwo systemu bankowego. Teoria i praktyka, Difin, Warszawa 2011.

Kubota T.: Concern About Financial Stability Following the Recent US Legal Expansionism: International Law and East Asian Perspectives [w:] Central Banking and Financial Stability in East Asia, red. F. Rövekamp, M. Bälz, H. G. Hilpert, Springer, Cham 2015.

Mitic P.: Reputation risk: measured, International Journal of Safety and Security Engineering 2018, Vol. 8, Issue 1, s. 171-180.

Morrison A. D., White L.: Reputational contagion and optimal regulatory forbearance, Journal of Financial Economics 2013, Vol. 110, Issue 3, s. 642-658.

Onyiriuba L.: Emerging Market Bank Lending and Credit Risk Control, Elsevier, London 2016.

Platt S.: Criminal capital; how the finance industry facilitates crime, Palgrave Macmillan, London 2015.

Tonello M.: Reputation risk - a corporate governance perspective, The Conference Board Research Report No. R-1412-07-WG, 2007.

Wang T., Hsu C.: Board composition and operational risk events of financial institutions, Journal of Banking \& Finance 2013, Vol. 37, Issue 6, s. 2042-2051.

Zaleska M.: Zarządzanie kryzysowe, [w:] Świat bankowości, red. M. Zaleska, Difin, Warszawa 2019.

\begin{abstract}
The purpose of the article is to review and analyse supervisory regulations and existing research in the area of reputational risk management in the modern banking system, with particular emphasis on methods for identifying and measuring this type of risk and instruments used to mitigate it. According to the author, reputational risk should be defined as a separate type of risk. However, due to its specific nature, it should not be managed separately, but together with the basic types of risk. The strategic postulate regarding mechanisms to mitigate reputational risk in the banking system is to limit the risk of bankruptcy of large, interrelated institutions by reducing their size and limiting interconnections, as well as improving the management of the efficient resolution of banks.
\end{abstract}

Key words: banks, reputational risk, operational risk.

JEL Codes: G21, G28, G32.

Informacje o autorze:

dr hab. Jan Koleśnik, prof. SGH

Szkoła Główna Handlowa w Warszawie

Kolegium Ekonomiczno-Społeczne

Instytut Bankowości

al. Niepodległości 162, 02-554 Warszawa

e-mail: jan.kolesnik@sgh.waw.pl

ORCID: 0000-0003-2182-5645 